\title{
KRAKÓW MIASTEM LITERATURY UNESCO - MIĘDZYNARODOWY PROGRAM PROMOCJ JAKO ELEMENT STRATEGII BUDOWANIA MARKI MIASTA
}

\author{
Abstract \\ Cracow City of Literature by UNESCO - International Promotion \\ Program as Part of Strategy to Build the Brand of the City
}

This paper reports the main assumptions and the participation of Cracow in the UNESCO Creative Cities. It's aim was therefore to show how participation in this type of project can affect the realization of the marketing strategy of the city in relation to the concept of territorial marketing.

Key words: Creative City, UNESCO, literature, territorial marketing, Cracow.

\section{Streszczenie}

Praca relacjonuje przebieg i główne założenia udziału Krakowa w programie Miasta Kreatywne UNESCO. Jej celem było zaprezentowanie jak udział w tego typu projekcie może wpływać na realizacje strategii marketingowej miasta w odniesieniu do koncepcji marketingu terytorialnego.

Słowa kluczowe: Miasto Kreatywne, UNESCO, literatura, marketing terytorialny, Kraków.

\section{Wstęp}

17 lutego 2016 roku Rada Miasta Krakowa przyjęła kolejną już uchwałę w sprawie programu Kraków Miasto Literatury UNESCO. Projekt programu jest co rok rozpatrywany ponownie na podstawie ewaluacji realizacji założeń z lat poprzednich. Zgłoszone w 2016 roku propozycje nie różniły się zasadniczo od przedstawionych w latach ubiegłych. Większość z nich to realizacja zadań cyklicznych, lecz program cieszy się dużym zainteresowaniem i pomimo obaw mieszkańców 
- związanych głównie z kwestiami finansowania planowanych w ramach programu wydarzeń, a także szeroko nagłaśnianą w mediach sprawą likwidacji kilku, cieszących się długą tradycją funkcjonowania, krakowskich księgarń - przedstawiany jest jako ogromny sukces promocyjny gminy miejskiej Kraków, ale również całego regionu. Celem niniejszej pracy jest analiza działań wynikających $\mathrm{z}$ realizacji założeń programu i ich rola w kształtowaniu wizerunku miasta w kontekście zagadnienia marketingu terytorialnego.

\section{Budowanie marki miasta - marketing terytorialny}

Marketing terytorialny jest, podobnie jak pokrewne, ale nietożsame, pojęcie marketingu miasta, jedną z nowych dziedzin, pogłębiającą zainteresowania wymianą dóbr i korzyści z niej płynących w świecie coraz silniej ogarniętym zjawiskiem globalizacji. Potrzeba zachowania tożsamości w warunkach konkurowania o ograniczone zasoby stoi u podstaw pojęcia marketingu terytorialnego, łączącego się ściśle z koniecznością wychodzenia naprzeciw potrzebom klientów i poszukiwania nowych partnerów biznesowych. Marketing terytorialny może zatem być „definiowany jako rynkowa koncepcja zarządzania jednostką osadniczą - jako zarządzanie zmierzające do zaspokojenia potrzeb i pragnień mieszkańców oraz «gości» przez wcześniejsze ich rozpoznanie i przewidywanie zmian, a jednocześnie oparte na racjonalnym wykorzystaniu całokształtu posiadanych zasobów" [Szromnik, 2011: 18].

Podstawą budowania marki miasta na podstawie koncepcji marketingu terytorialnego jest specyficzny produkt czy też właściwość regionu. Nie jest to łatwe zadanie w warunkach dużej konkurencyjności, kiedy wypromowanie kolejnego produktu jest niezwykle trudne, ponieważ wymaga zastosowania innowacyjnych technik promocji, które trafią do szerokiej grupy odbiorców, nie obniżając przy tym wartości produktu do formy codziennej i banalnej.

Nieco inne podejście do marketingu terytorialnego prezentuje Valerie Girard. „Zgodnie z jej koncepcją marketing terytorialny obejmuje zespół technik i działań, zastosowanych przez społeczności lokalne i organizacje w trakcie procesu planowania projektu rozwoju ekonomicznego, turystycznego, urbanistycznego, społecznego, kulturowego lub też projektu o charakterze tożsamościowym" [Szromnik, 2011: 22.]. Marketing terytorialny jest tu zatem traktowany jako forma realizacji projektu i powinien być stosowany konsekwentnie od początku do końca jego realizacji. Co więcej, V. Girard zwraca uwagę na istnienie ekonomicznych, ale również nieekonomicznych celów realizacji projektów promocyjnych [por. Girard, 1997: 85].

Marketing terytorialny należy rozpatrywać w odniesieniu do dwóch sfer oddziaływania: wewnętrznej i zewnętrznej. Wyszczególnienie to dotyczy głównie adresatów działań marketingowych jednostki terytorialnej. Do sfery wewnętrznej wlicza się zatem interesariuszy permanentnie związanych z funkcjonowaniem gminy/miasta, jak na przykład: mieszkańców, miejscowe organizacje dochodowe 
lub niedochodowe. Marketing zewnętrzny zaś to działania ukierunkowane na podmioty umiejscowione poza obszarem danej jednostki terytorialnej, skłonne do podjęcia z nią współpracy i przemieszczenia oferowanego przez siebie kapitału. Andrzej Szromnik wskazuje na konieczność dokonania bardziej szczegółowego wyróżnienia, mianowicie sugeruje podział marketingu wewnętrznego na dwie kolejne podgrupy: marketing wewnętrzny I i marketing wewnętrzny II, gdzie I oznacza „całokształt relacji, powiązań oraz działań inicjowanych przez władze jednostki osadniczej, a ukierunkowanych na szeroką grupę pracowników instytucji samorządowych i komunalnych [...]. Terminem marketing wewnętrzny II w mieście czy regionie określa się zaś te czynności, operacje oraz całościowe przedsięwzięcia, które stymulują pożądane zachowania mieszkańców, ich grup, a także przedsiębiorstw i instytucji niekomercyjnych zlokalizowanych $\mathrm{w}$ danej jednostce przestrzennej" [Szromnik, 2011: 31.].

Szybki rozwój, dynamika ruchów migracyjnych i szereg innych procesów społeczno-gospodarczych przyczyniają się do konieczności budowania przez miasta wizerunku nie tylko w sferze oddziaływań lokalnych, ale również globalnie. Przykłady wielu miast świata pokazują, że umiejętnie planowana i sprawnie wdrażana strategia marketingowa może się przyczynić do poprawy bądź stworzenia wizerunku miasta na arenie światowej, a co za tym idzie - polepszenia jego sytuacji ekonomicznej. Marketing terytorialny jest jednym z głównych narzędzi wymienianych $\mathrm{w}$ dyskusji na temat budowania wizerunku miasta. Pojawiają się również stwierdzenia, które sugerują, że marketing terytorialny należy traktować jako narzędzie zarządzania rozwojem jednostki terytorialnej [Kobylińska, 2011].

Urszula Kobylińska wymienia trzy komponenty budujące zarządzanie wizerunkiem miasta, mianowicie: tożsamość, wizerunek i markę. Pojęcia te, chociaż bliskoznaczne, różnią się zakresem znaczeniowym. Tożsamość należy rozumieć jako zestaw uświadamianych sobie przez grupy zainteresowane, tu głównie mieszkańców, cech obiektu, w tym przypadku: miasta. Tożsamość buduje się przez lata, jest wypadkową tego, co miasto przekazuje na swój temat otoczeniu. Wizerunek z kolei stanowi zbiór symboli i znaków, które zapewniają miastu lub instytucji rozpoznawalność, buduje się go, opierając się na tożsamości, jest jednak zorientowany bardziej zewnętrznie, liczy się tu bowiem nie tylko to, co sami o sobie mówimy, ale również to, co czyni nas rozpoznawalnymi. Ostatni komponent to marka miasta rozumiana jako zbiór elementów fizycznych i emocjonalnych, które tworzą rodzaj tropów kulturowych w świadomości odbiorców [Kobylińska, 2011]. Zarówno wizerunek, jak i tożsamość stanowią elementy składowe budujące markę, wszystkie razem są zaś nieodłącznym elementem budowania strategii marketingowej miasta. Bez dokładnego rozpoznania komponentów nie można zbudować odpowiedniej strategii, która przyniesie pożądane skutki dla rozwoju miasta.

Nie bez znaczenia jest tu również efekt wzmocnienia synergicznego wywoływany przez nakładanie się wpływów. Miasto nie znajduje się w próżni, otoczenie organizacyjne i dynamiczna sytuacja społeczna sprawiają, że kontekst polityczno-ekonomiczny ulega ciągłej zmianie. Wzmocnienie synergiczne to czynnik oddziałujący ,na marketingową siłę gminy, powiatu lub województwa [...] będący efektem nałożenia się różnorodnych środków stymulowania zainteresowanych grup 
odniesienia, inicjowanych w realizowanych przez różne podmioty wewnętrzne i zewnętrzne, ale umiejętnie koordynowanych i wykorzystywanych przez służby marketingowe danej jednostki terytorialnej" [Szromnik, 2011: 35.].

Budowanie marki miasta stanowi niezbędny element dla jego rozwoju. Skutecznie wdrażana strategia marketingowa pozwala miastu zaistnieć i stać się rozpoznawalnym, a co za tym idzie - dobrze zbudowana marka ułatwia budowanie kontaktów biznesowych, otwiera drzwi do nowych inwestycji i dalszego rozwoju. Ważne jest, aby podczas kreowania wizerunku miasta nie zaprzeczać tożsamości i tradycji zakorzenionej w regionie, ale starać się wkomponować te elementy w budowaną strategię i wykorzystać je do stworzenia nowej jakości.

\section{Kraków wśród Miast Kreatywnych UNESCO}

Pojęcie kreatywności kojarzone jest najczęściej z tworzeniem czegoś nowego na podstawie istniejących idei. Najistotniejszą cechą kreatywnego działania jest oryginalność pomysłu. Podobnie „kreatywne miasto to środowisko, w którym wartości spełniają funkcję katalizatorów rozwoju, gdzie artyści i inni uczestnicy określani klasą kreatywną odgrywają zasadniczą rolę" [Rogowska, 2013: 157].

Program Miast Kreatywnych UNESCO powstał w 2004 roku, ,,aby promować rozwój ekonomiczny, społeczny i kulturalny miast oparty na zasadach trwałego i zrównoważonego rozwoju" [Zgłoszenia do sieci miast kreatywnych UNESCO, 19.01.2016]. Zasięgiem obejmuje cały świat. Każde miasto, które zobowiąże się do spełnienia warunków wstępnych, opisanych w regulaminie, może się starać o przyznanie mu tytułu Miasta Kreatywnego w jednej z wybranych dziedzin; mianowicie: muzyka, film, rzemiosło artystyczne, literatura, sztuka ludowa, wzornictwo, media art lub gastronomia. Podsumowanie dokonane w 2016 roku wykazało, że program w 2015 zrzeszał 54 kraje, w tym 116 miast z obszaru Europy, Azji, Australii, Afryki i obu Ameryk. Podstawowym założeniem programu jest współpraca oparta na wymianie wiedzy i doświadczeń w obszarze promocji i rozwoju kultury regionalnej. Miasta Kreatywne dzielą się wiedzą i wzajemnie promują swoje dokonania, wspierają się również w kreowaniu nowych rozwiązań dla rynku przedsiębiorczości kreatywnej, nie ograniczając się przy tym do tradycyjnie pojmowanej kultury i sztuki, ale inwestując w nowe technologie. Dodatkowe wsparcie stanowi patronat UNESCO, organizacji rozpoznawalnej na całym świecie, która koordynuje program i dba o jakość promowanych projektów [Creative Cities Network, 19.01.2016].

W 2011 roku Prezydent Miasta Krakowa złożył wniosek aplikacyjny do UNESCO w sprawie przyznania miastu tytułu Miasta Kreatywnego w dziedzinie literatury. Zgłoszenie chęci udziału wiąże się z koniecznością spełnienia szeregu wymagań i wykazania się inicjatywą w danym obszarze. Aby uzasadnić, dlaczego stolica Małopolski zasługuje na ten tytuł, zespół ekspertów przygotowujących wniosek wymienił 10 powodów; w tym: przyznany miastu w 2010 roku tytuł Stolicy Kultury, wielowiekowe dziedzictwo literackie, mnogość ośrodków edukacyjnych 
i instytucji literackich, a także organizowane tu festiwale i przyznawane stypendia związane $\mathrm{z}$ twórczością i rynkiem wydawniczym. Jednym z walorów były też cieszące się dużą popularnością targi książki. Miano Miasta Literatury miało zatem stanowić nie wyzwanie, ale raczej zobowiązanie do utrzymania poziomu i dalszego rozwijania już rozpoczętych inicjatyw. W publikacji Urzędu Miasta Krakowa, zatytułowanej Krakow City of Literature, zebrano kierunki działań, na rozwój których wpłynie zaangażowanie miasta w program:

1. wzmacniać działania w obszarze literackiego dziedzictwa miasta; 2. inspirować powstawanie nowych inicjatyw; 3. pomagać w tworzeniu i promowaniu obecności literatury w codziennym życiu mieszkańców; 4 . pomagać w dalszym dynamicznym rozwoju tej dziedziny gospodarki kreatywnej na płaszczyźnie lokalnej, regionalnej, makroregionalnej i międzynarodowej [Krakow City of Literature, 2013: 66].

Zaktualizowany w 2013 roku wniosek zawiera również wstępny plan finansowania programu. W listopadzie 2013 roku powołano Regionalny Fundusz Literatury, co miało ułatwić koordynacje funduszy przeznaczonych na realizację programu, natomiast Strategie Miasta Literatury w jej ostatecznym kształcie ogłoszono w grudniu 2013 roku, wtedy również rozpisano pierwsze konkursy na projekty realizowane $\mathrm{w}$ ramach programu. Łącznie na finansowanie programu Kraków Miasto Literatury przeznaczono w 2014 roku 2,4 mln zł. Kwota ta obejmuje głównie środki i dofinansowania celowe dla Regionalnego Funduszu Literatury, dotacje z Urzędu Marszałkowskiego oraz Ministerstwa Kultury i Dziedzictwa Narodowego. Wkład gminy miejskiej Kraków wynosił 500 tys. zł. Kwota ta obejmuje środki dodatkowe z przeznaczeniem na Regionalny Fundusz Literatury oraz 600 tys. zł z funduszy Krakowskiego Biura Festiwalowego przeznaczone na realizację festiwali literackich. Łączny przewidywany dla programu budżet na lata 2014-2016 miał wynosić 7,2 mln zł, plus środki dodatkowe pozostające w dyspozycji Wydziału Kultury i Dziedzictwa Narodowego Miasta Kraków w ogólnej kwocie 15,124 mln zł [Krakow City of Literature, 2013: 63].

W 2013 roku, na konferencji w Pekinie, Kraków otrzymał oficjalnie tytuł Miasta Literatury. W konferencji brali udział przedstawiciele około stu miast z całego świata. W ten sposób Kraków stał się siódmym wyróżnionym w tym mianem ośrodkiem literackim, pierwszym słowiańskim, a drugim nieanglojęzycznym Miastem Literatury na świecie. Jako główny element wyróżniający polską aplikację wskazano ambitne projekty angażujące nowe technologie, a także harmonijne współistnienie wielu elementów budujących wizerunek miasta nowoczesnego, które inspiracje do rozwoju czerpie z silnych i głęboko zakorzenionych tradycji.

Mając na uwadze przyznany tytuł Miasta Literatury UNESCO oraz potrzebę stworzenia programu wspierającego różnorodność i bogactwo krakowskich inicjatyw literackich, Rada Miasta Krakowa podjęła w dniu 6. listopada 2013 r. uchwałę Nr LXXXVIII/1319/13 w sprawie opracowania programu Kraków Miasto Literatury. Towarzyszyło temu przekonanie, że literatura może przyczyniać się do poprawy spójności społecznej, stymulować rozwój gospodarczy i rozwój przemysłów kreatyw- 
nych oraz istotnie wpływać na dialog międzykulturowy [Kraków Miastem Literatury UNESCO, 23.02.2016].

Informacja o rozpoczęciu starań o przyznanie miastu tytułu Miasta Kreatywnego spowodowała pojawienie się wielu sceptycznych głosów. Opinie publikowane na forach internetowych wskazywały na brak zaufania co do słuszności decyzji związanych z takim spożytkowaniem środków finansowych. Mimo to miasto, przy wsparciu Krakowskiego Biura Festiwalowego, rozpoczęło intensywne działania promujące program. W ramach realizacji idei Miasta Literatury zaplanowano organizację festiwali literackich, akcji promujących czytelnictwo, wsparcie dla lokalnego rynku księgarskiego i bibliotek, a także działania wspierające rozwój kreatywnych pomysłów biznesowych opartych na ideach związanych z szeroko pojmowaną książką i literaturą. Burzliwe dyskusje na łamach, głównie internetowych, mediów ucichły na jakiś czas. Prawdopodobnie największy wpływ na taki rozwój wypadków miała szybka reakcja władz samorządowych, oparta na solidnie przygotowanej strategii działań. Silna współpraca z Krakowskim Biurem Festiwalowym, doświadczonym w przygotowywaniu imprez i planowaniu wydarzeń kulturowych, a także przeprowadzone wcześniej szeroko zakrojone konsultacje pomogły przygotować strategię działań opartą na przemyślanych wyborach. O rozwoju programu świadczy między innymi rosnąca liczba zgłaszanych i realizowanych w jego ramach projektów. Co również korzystne, program angażuje także małe społeczności lokalne (dzielnice), poprzez akcje prowadzone w bibliotekach czy klubach osiedlowych.

\section{Kraków Miasto Literatury - program budujący markę miasta}

Wniosek wstępny zawierający dziesięć powodów, dla których Kraków miałby otrzymać tytuł Miasta Literatury, wymieniał przede wszystkim elementy wizerunkowe, dzięki którym miasto jest rozpoznawane w Polsce i na świecie, a więc wielowiekowe tradycje, ośrodek uniwersytecki, ważne dla kultury zbiory biblioteczne, między innymi księgozbiór Biblioteki Jagiellońskiej czy obecność noblistów. Ponieważ jednak Miasta Kreatywne UNESCO to program wieloletni, postawiono sobie też liczne, przede wszystkim organizacyjne, wyzwania, z którymi Kraków musiał się zmierzyć. Należy tu wspomnieć chociażby o imprezach organizowanych cyklicznie w formie festiwalowej: Festiwalu Conrada i Festiwalu Miłosza czy Targach Książki, które już na stałe wpisały się w kalendarz imprez organizowanych w mieście. Festiwal Conrada, mimo swej nazwy, nie jest poświęcony twórczości Josepha Conrada. Nazwisko autora zostało wykorzystane w formie symbolu, który wskazuje na ponadnarodowy wymiar literatury, gromadząc twórców z całego świata, w tym znanych i nagradzanych w środowisku literackim autorów [por. Festiwal Conrada - Idea, 14.12.2016]. Drugim ważnym wydarzeniem w kalendarzu imprez literackich w Krakowie jest Festiwal Miłosza. Jest to kontynuacja idei spotkania poetów ze wschodu i zachodu zapoczątkowana 
przez krakowskich noblistów Czesława Miłosza i Wisławę Szymborską. Pięć lat po śmierci Miłosza Instytut Książki zorganizował pierwszy festiwal poezji w Krakowie, w 2014 roku pieczę nad organizacją festiwalu przejęło Krakowskie Biuro Festiwalowe i Fundacja Miasto Literatury, nie zmieniając jednak jego poetyckiego charakteru [por. Festiwal Mitosza - O festiwalu, 14.12.2016].

Za poziom oferowanych w ramach programu wydarzeń odpowiada Krakowskie Biuro Festiwalowe, osiągając relatywnie dobre wyniki, bowiem z każdym kolejnym rokiem krakowskie festiwale literackie odwiedzają coraz większe rzesze wielbicieli literatury. Festiwal Conrada w tegorocznej edycji odnotował rekord frekwencji-20 tys. osób, które uczestniczyły w spotkaniach, wykładach i konferencjach. Prestiż festiwalu wzmocniła również obecność noblistki - Swietłany Aleksijewicz, która odwiedziła Kraków niedługo po otrzymaniu nagrody. Festiwal Conrada to jednak nie tylko wydarzenie promujące nagradzanych i popularnych $\mathrm{w}$ świecie literatury twórców, ale również precyzyjnie opracowana akcja promocyjna, wspierająca rodzimy rynek książki, jak również pasma tematyczne, poświęcone na przykład grom komputerowym. Podobnym sukcesem i kolejnymi rekordami cieszyły się, odbywające się równolegle z Festiwalem Conrada, Targi Książki, które w 2015 roku odwiedziło około 70 tys. zwiedzających swoje produkty prezentowało blisko 700 wystawców z 27 krajów, dodatkowym atutem była możliwość spotkania z autorami, w 2015 roku było to aż 700 osób z Polski i zagranicy. Owocem tegorocznych spotkań organizowanych w ramach Festiwalu Miłosza było wzbogacenie polskiej oferty wydawniczej o kolejnych autorów, do tej pory niedostępnych na naszym rynku. Dodatkowym elementem zorganizowanym po raz pierwszy w 2015 roku był Festiwal Literatury dla Dzieci. Kraków promował w ten sposób czytelnictwo wśród najmłodszych mieszkańców, ale również podjął współpracę z innymi polskimi miastami (Warszawa, Gdańsk, Wrocław), które zorganizowały u siebie podobne akcje. W 2015 roku, również po raz pierwszy, Miasto Literatury zagościło na organizowanym na Kazimierzu Festiwalu Kultury Żydowskiej, organizując akcje kierowane do dzieci, czytelnie, spotkania z autorami oraz warsztaty pisarskie dla seniorów [Kraków Miastem Literatury UNESCO, 23.02.2016]. Większość z tych akcji odbywałaby się zapewne bez względu na udział Krakowa w programie, jednak rozgłos zapewniany przez UNESCO i sieć współpracy międzynarodowej ułatwia i przyspiesza niektóre procesy.

Innym, konsekwentnie realizowanym, postulatem Miasta Literatury jest łączenie tradycji z nowymi technologiami. Na tym polu szczególną popularnością cieszą się aplikacje wspierające czytelnictwo w programie: Czytaj PL. Aplikacja została pobrana aż 10 tys. razy, w rezultacie czego wypożyczono 20 tys. e-booków lub fragmentów tekstów. Tegoroczna edycja akcji odbywała się nie tylko w Krakowie, ale również w Warszawie, Wrocławiu, Poznaniu, Katowicach i Gdańsku. Nadal trwa, i obejmuje kolejne ławki na krakowskich plantach, akcja Kody Miasta, w ramach której ławki opatrywane są kodem QR, pozwalającym pobrać interaktywną informację o patronie siedziska. Przy współudziale miast partnerskich (Nowy Jork, Londyn, Guadalajara) zorganizowano również dwie edycje nowego wydarzenia: BeaconValley Hackathon. Jest to spotkanie programistów, trwające 24 godziny, w czasie którego wspólnie tworzą oni technologie wspierające rozwój 
kultury i wykorzystujące beacony. Owocem pracy techników była interaktywna gra miejska Cała naprzód wykorzystana podczas Festiwalu Conrada. Dodatkowo udało się również wydać grę planszową wykorzystującą motywy z serii znanych kryminałów, na co środki zebrano podczas akcji crowdfundingowej [Kraków Miastem Literatury UNESCO, 23.02.2016].

Kolejną ważną inicjatywą, bez której Kraków nie mógłby szczycić się tytułem miasta z tradycją literacką, jest miejscowy rynek książki. W ramach akcji Czytaj Lokalnie wspierano małe księgarnie i antykwariaty w sprzedaży swoich produktów, zapewniając na przykład specjalne gadżety promocyjne. W ochronę lokalnego rynku księgarskiego zaangażowała się również bezpośrednio Rada Miasta, poprzez uchwałę NR XXII/365/15 Rady Miasta Krakowa z dnia 26 sierpnia 2015 r. o branżach chronionych. Stanowiła ona rozszerzenie uchwały z 2009 roku o dodatkowe elementy związane z rozwojem działalności księgarskiej. Miasto rozpisało również konkurs dla organizacji pozarządowych na projekty organizowane w przestrzeni księgarń.

Program Miast Kreatywnych przynosi efekty marketingowe i jako strategia na kolejne lata promocji i rozwoju działa sprawnie, chociaż należy wskazać, że jest to związane przede wszystkim z umiejętnym wykorzystywaniem zasobów i systematycznym podążaniem za trendami. Mimo licznych działań promocyjnych i sukcesu organizacyjnego festiwali, wydarzenia zaplanowane w ramach programu Miasto Literatury odbywały się w 2015 roku w cieniu kolejnej fali krytyki skierowanej w stronę władz miasta. Było to związane przede wszystkim z zamknięciem kilku działających przez wiele lat w obrębie centrum księgarń. W wywiadzie dla Radia Kraków Szymon Kloska sceptycznie wypowiadał się na temat polityki miasta i związanej z nią przyszłości krakowskiego rynku księgarskiego:

Księgarni przed przyznaniem Krakowowi tytułu Miasta Literatury było więcej, jeszcze parę lat przed przyznaniem stanowczo więcej. Pewne ruchy są wykonywane, są dobre kierunki, ale jest ich stanowczo za mało. Zamknięcie księgarni to sytuacja trudna do odwrócenia. Księgarze, którzy mają swoje pomysły, mogą zniknąć, a znalezienie ludzi z podobnymi kompetencjami może być trudne, pomijając fakt, że lokale miejskie mogą być pozajmowane przez inne biznesy. Na obecny moment sytuacja wygląda dość krytycznie, gdzie za jakiś czas w obrębie Plant nie będzie gdzie kupić książki, co w mieście noszącym tytuł Miasta Literatury UNESCO było sytuacją skandaliczną" [Rozmowa Anny Łoś z Szymonem Kloską, Kolejna znana księgarnia znika z mapy Krakowa, 14.12.2016].

Opublikowanie tej informacji w ciągu kilku dni doczekało się kilkudziesięciu wyrażających oburzenie komentarzy mieszkańców, zarzucających władzom miasta pozbawiania Krakowa charakteru ośrodka kultury.

Program Miasto Literatury wpływa jednak znacząco także na inne sfery życia miasta. Liczne wydarzenia przyciągają turystów z kraju i zagranicy, wzmacniając tym samym i tak już intensywny ruch turystyczny w mieście. Cykliczność wydarzeń, szczególnie festiwali, i duże nakłady związane z ich promocją powinny jednak sprzyjać wyspecjalizowaniu się miasta w określonym rodzaju turystyki, 
przyciągających pewną elitarną grupę odbiorców. Turystyka literacka, sama w sobie, stała się trendem wartym śledzenia. Dzięki wsparciu dla tworzenia i uatrakcyjnianiu szlaków ma ona szanse stać się jedną z bardziej rozpoznawalnych atrakcji Krakowa. Zaangażowanie specjalistów w generowanie nowych rozwiązań zapewniło przepływ innowacyjnych pomysłów wykorzystujących motywy literackie. Jednocześnie dodano do wizerunku miasta z tradycjami element nowoczesności, która stała się atrakcyjnym uzupełnieniem wizji miasta, w którym klasycznemu elementowi dziedzictwa kulturowego nadaje się nową wartość. Kierunek rozwoju, skonstruowany na podstawie zdiagnozowanego potencjału wydaje się przekonującym pomysłem w kontekście kreowania marki Miasta Literatury. O sile marketingowej programu może świadczyć również fakt, że w tym roku po raz pierwszy Kraków i Wrocław dołączyły do grona wystawców w Salonie Książki w Paryżu - była to pierwsza taka akcja promocyjna od niemal 15 lat. Mimo promocyjnych sukcesów statystyki wskazują jednak, że grupa turystów odwiedzających Kraków z powodu udziału w wydarzeniach kulturalnych spadła w stosunku do roku 2013, zarówno w kontekście turystów zagranicznych (spadek z 3,5\% do 1,4\% ), jak i polskich (z 1,7\% do poziomu 1,2\%) [por. Raport o stanie miasta 2015, 2015: 104].

Jednym z zadań dla miasta wskazywanym we wniosku aplikacyjnym było także promowanie czytelnictwa. Chociaż brak potwierdzenia bezpośredniego związku pomiędzy prowadzonymi akcjami społecznymi, których celem jest popularyzowanie czytania w różnych grupach wiekowych, to statystyki wskazują na znaczny wzrost w tej kwestii w 2015 roku. Liczba książek wypożyczonych w krakowskich bibliotekach gminnych wzrosła w porównaniu do 2014 roku o ponad 90 tys. [ $R a-$ port o stanie miasta 2015, 2015: 154]. Największe wyzwanie w tym kontekście będzie jednak realizowane w 2017 roku. Powzięto bowiem inicjatywę zmiany struktury bibliotek publicznych w mieście. Nowa instytucja, nazwana Biblioteką Kraków, ma odejść od przedawnionego systemu czterech oddzielnych bibliotek dzielnicowych, tworząc jedną spójna instytucję. Projekt jest jednak dopiero w fazie realizacji [Por. Biblioteka Kraków, 13.12.2016].

\section{Podsumowanie}

Kraków Miasto Literatury to program łączący w sobie wiele elementów sprzyjających rozwojowi działań marketingowych. W tym wypadku umiejętnie wykorzystano ten potencjał, opierając akcje promocyjną na elementach powszechnie uznawanych za elitarne i niszowe. Medialny sukces programu i projektowane w jego ramach działania wspierające rodzimy rynek książki nie są jednak wystarczające, aby zatrzymać proces znikania księgarń z centrum miasta. Ogólnoświatowe trendy związane ze wzrostem popularności e-booków i audiobooków również wpływają na coraz słabszą pozycję księgarzy na rynku. Jakby w opozycji do likwidowania księgarń w Krakowie odnotowano jednak wzrost czytelnictwa, co oznacza, że mieszkańcy chętniej odwiedzają biblioteki. 
Tytuł Miasta Literatury okazał się dobrym ruchem marketingowym, szczególnie w kontekście kreowania wizerunku w międzynarodowym środowisku i nadania miastu specyficznego charakteru. Promowanie regionu przy wykorzystaniu istniejącego potencjału, a jednocześnie wspieranie rozwoju, wyjście naprzeciw panującym trendom bez oderwania od elementu tożsamości było trudnym zadaniem i mogło się udać wyłącznie dzięki ścisłej współpracy wielu podmiotów. W tym przypadku władze miasta wybrały dobrą rolę koordynatora, niewyróżniającego się, a jednocześnie posiadającego decydujący głos w podejmowanych inicjatywach. Można tu mówić o zaistnieniu efektu synergii, którego ogromne znaczenie podkreśla A. Szromnik, zaznaczając, że „w marketingu terytorialnym, warto szczególnie zaakcentować to, że nie sztuką jest dla organów władz lokalnych prowadzić samodzielne działania marketingowe, ale umiejętnie włączyć się i wykorzystywać dla własnych celów przedsięwzięcia marketingowe, realizowane przez podmioty «obce», a zwłaszcza przedsiębiorstwa i ich grupy" [Szromnik, 2011: 36.]. Włączenie się w program Miast Kreatywnych UNESCO, chociaż wymaga wielu wysiłków organizacyjnych i wiąże się z ryzykiem wynikającym z konieczności pozyskiwania zewnętrznych źródeł finansowania, niewątpliwie przynosi efekty. Jednym z celów planowanych na 2016 rok było złożenie do Urzędu Miasta projektu zakładającego stałe finansowanie dla programu Miasto Literatury na kolejne lata. Dzięki takiej uchwale wzrosłoby zarówno bezpieczeństwo realizacji poszczególnych projektów, jak i prestiż samego programu, na stałe wkomponowanego w życie miasta.

\section{Bibliografia}

Biblioteka Kraków. Kierunki rozwoju jednolitej sieci miejskich bibliotek w Krakowie - projekt badawczo-konsultacyjny MIK, http://badania-w-kulturze.mik.krakow.pl/2016/08/08/ biblioteka-krakow-kierunki-rozwoju-jednolitej-sieci-miejskich-bibliotek-w-krakowie-projekt-badawczo-konsultacyjny-mik/ [dostęp: 12.12.2016].

Creative Cities Network UNESCO, http://en.unesco.org/creative-cities/creative-cities-map] [dostep: 19.01.2016].

Festiwal Conrada - Idea, http://conradfestival.pl/p/10,idea1 [dostęp: 12.12.2016].

Festiwal Miłosza - O festiwalu, http://miloszfestival.pl/informacje/o-festiwalu/ [dostęp: 14.12.2016].

Girard V. (1997), Marketing terytorialny i planowanie strategiczne [w:] T. Domański (red.), Marketing terytorialny. Strategiczne wyzwanie dla miast i regionów, Uniwersytet Łódzki, Łódź.

Kobylińska U. (2011), Współczesne wyzwania dla miejskich samorząów w zakresie kreowania wizerunku, „Ekonomiczne Problemy Usług”, nr 75 (663).

Krakow City of Literature (2013), Urząd Miasta Krakowa - Wydział Kultury i Promocji Miasta, Kraków.

Kraków Miastem Literatury UNESCO, Fundacja Kraków Miasto Literatury, http://miastoliteratury.pl/miasto-literatury/przemysly-kreatywne/ [dostęp: 23.02.2016]. 
Łoś A., Kolejna znana księgarnia znika z mapy Krakowa - rozmowa z Szymonem Kloska, http://www.radiokrakow.pl/wiadomosci/krakow/kolejna-znana-ksiegarnia-znika-z-mapy-krakowa/ [dostęp: 17.01.2015].

Raport o stanie miasta 2015 (2015), Urząd Miasta Krakowa - Wydział Rozwoju Miasta, file://C:/Users/pc/Desktop/166047_0.pdf [dostęp: 12.12.2016].

Rogowska M. (2013), Koncepcja kreatywnego miasta $w$ teorii i praktyce, file://C:/Users/pc/ Desktop/Rogowska_Koncepcja_kreatywnego_miasta_w_teorii.pdf [dostęp: 29.02.2017].

Szromnik A. (2011), Marketing terytorialny jako atrybut rynkowej orientacji miast oraz regionów [w:] A. Grzegorczyk, A. Kochaniec (red.), Kreowanie wizerunku miasta, Wyższa Szkoła Promocji, Warszawa.

Uchwała Nr XXII/365/15 Rady Miasta Krakowa z dnia 26 sierpnia 2015 r. w sprawie zmiany uchwaty Nr LXXXI/1060/09 Rady Miasta Krakowa z dnia 23 września 2009 r. w sprawie przyjęcia programu gospodarczego wspierania przedsiębiorczości w zakresie branż chronionych $i$ zanikajacych, https://www.bip.krakow.pl/?dok_id=167\&sub_dok_id=167\& $\mathrm{sub}=$ uchwala\&query=id\%3D17940\%26typ\%3Du [dostęp: 29.02.2017].

Uchwała Nr LXXXVIII/1319/13 Rady Miasta Krakowa z dnia 6 listopada 2013 r. w sprawie opracowania programu Kraków Miasto Literatury, https://www.bip.krakow.pl/?dok $\mathrm{id}=167 \&$ sub_dok_id=167\&sub=uchwala\&query=id\%3D19930\%26typ\%3Du\&metka=1 [dostęp: 29.02.2017].

Uchwała Nr XXXVII/632/16 Rady Miasta Krakowa z dnia 17 lutego 2016 r. w sprawie przyjęcia programu Kraków - Miasto Literatury UNESCO, https://www.bip.krakow.pl/?dok $\mathrm{id}=167 \&$ sub_dok_id=167\&sub=uchwala\&query=id\%3D21281\%26typ\%3Du [dostęp: 29.02. 2017].

Zgłoszenia do sieci miast kreatywnych UNESCO, Polski Komitet ds. UNESCO, http://www.unesco. $\mathrm{pl} /$ neste/2/article/1/zgloszenia-do-sieci-miast-kreatywnych-unesco/ [dostęp: 19.01.2016]. 